УДК 379.857

DOI 10.18101/2304-4446-2020-2-34-40

\title{
ВОДНЫЙ ТУРИЗМ \\ КАК ОДНО ИЗ НАПРАВЛЕНИЙ В РЕКРЕАЦИИ
}

\section{(c) Старкова Ирина Ивановна}

кандидат социологических наук, доцент,

Бурятский государственный университет имени Доржи Банзарова

Россия, 670000, г. Улан-Удэ, ул. Смолина, 24а

E- mail: irina-ivanovna.8@mail.ru

\section{(C) Крыласова Екатерина Александровна}

старший преподаватель кафедры физического воспитания, Бурятский государственный университет имени Доржи Банзарова Россия, 670000, г. Улан-Удэ, ул. Смолина, 24a

E-mail: krylasova@yandex.ru

\section{(C) Доржиева Лариса Геннадьевна}

кандидат педагогических наук, старший преподаватель кафедры физического воспитания,

Бурятский государственный университет имени Доржи Банзарова Россия, 670000, г. Улан-Удэ, ул. Смолина, 24а

E-mail: lara.dorzhieva@yandex.ru

Республика Бурятия является привлекательным регионом в плане развития водного туризма, который в Бурятии имеет большой потенциал для благоприятного развития внутреннего туризма и приема туристов, в том числе иностранных. Водный туризм это один из видов спортивного туризма, заключающийся в преодолении препятствий по водной поверхности, что дает возможность как активного, так и пассивного отдыха. В статье представлены виды водного туризма, обоснованные как отдельное направление в рекреации. Авторы делают вывод о том, что водный туризм сочетает в себе элементы познания, активного отдыха, оздоровления и спорта и доступен всем здоровым людям.

Ключевые слова: рекреация; водный туризм; туризм; отдых; организация досуга.

\section{Для цитирования}

Старкова И. И., Крыласова Е. А., Доржиева Л. Г. Водный туризм как одно из направлений в рекреации // Вестник Бурятского государственного университета. Экономика и менеджмент. 2020. № 2. С. 34-40.

Водный вид туризма - это туры, организованные в экологические нетронутые уголки природы. К данному виду туризма относят разные экспедиции, плавание на яхтах и сплавы по горным рекам (рафтинг) ${ }^{1}$. Единого определения понятия «водный туризм» не существует. Литературный обзор показывает, что каждый исследователь обозначает термин «водный туризм» по-своему.

${ }^{1}$ Отчет Всемирного совета по путешествиям и туризму по России [Электронный pecypc]. URL: http://www.wttc.org/site_media/uploads/downloads/russian_federation2012.pdf (дата обращения: 11.03.2020). 

направлений в рекреации

С. Н. Бабурин считает, что водный туризм - это вид туризма, при котором отдых осуществляется на воде с использованием байдарок, лодок, катамаранов, теплоходов и других плавательных средств [1]. По А. Н. Кугушеву, водный туризм - это один из видов спортивного туризма, который заключается в преодолении маршрута по водной поверхности такими способами, как сплав по рекам, парусный туризм, морской каякинг. В. В. Плис отмечает, что водный туризм является спортивным туризмом, за исключением каких-либо путешествий по воде, которые осуществляются с рекреационной целью (круизы). Существует множество разнообразных видов такого туризма, которые различаются между собой по сложности прохождения и по способу управления плавсредствами. Например, А. М. Пучкин к водному туризму относит абсолютно все виды отдыха на воде, не только экстремальные.

Указанные авторы считают, что понятие «водный туризм» включает в себя и экстремальный туризм, и спокойное времяпровождение, и отдых на воде, который осуществляется с использованием различных видов водного транспорта для преодоления маршрута по воде путем сплава. К водному туризму также относят парусный туризм и морской каякинг.

На наш взгляд, водный туризм объединяет в себе и познание окружающего мира, и активный отдых, и оздоровление организма, и спорт. Высокий уровень комфорта, большая вместимость, реализация различных видов и целей туризма (и познавательный, и паломнический, и бизнес-туризм), возможность полноценного и комплексного отдыха - все это делает данный вид туризма массовым и популярным. Вместе с тем следует отметить такие факторы, как невысокая скорость движения судна, ограниченная мобильность, часто возникающая «морская болезнь» у людей, а также зависимость от погодных условий [2].

Для организации туров в водном туризме используют спортивные суда каркасной, каркасно-надувной, надувной конструкции, приводимые в движение силой течения (рафтинг), мускульной силой (сплав, каякинг) или силой ветра (парусный туризм). Водные туры можно разделить на шесть категорий: первые три категории - это несложные маршруты с минимальным количеством препятствий, например, небольшие мели или перекаты, отмели, данные маршруты доступны для новичков; а следующие три категории предназначены для хорошо подготовленных туристов, где нельзя допускать ошибки, которые могут привести к серьезным последствиям. Россия как страна с большим разнообразием водных ресурсов позволяет совершать путешествия любой сложности.

1. Одним из наиболее популярных видов водного туризма являются сплавы, которые, в свою очередь, подразделяются на сложные (для подготовленных групп туристов) и простые маршруты (для новичков). Сплавы хороши как активный вид отдыха для всей семьи. Во время таких сплавов можно наслаждаться живописными берегами рек, завораживающей природой, высадиться и прогуляться по береговой линии. Сплавы прекрасно сочетаются с познавательным туризмом и дают возможность знакомства с культурно-историческими достопримечательностями. Для сплавов используют катамараны, плоты, надувные лодки, которые движутся за счет течения воды либо с помощью весел или мотора.

2. Рафтинг подразумевает под собой сплав по бурным горным рекам с порогами, водопадами и перекатами. Рафт - это большое надувное, бескаркасное 
судно, которое обладает большой плавучестью, они надежны и устойчивы на воде, а также могут вмещать от 6 до 12 человек, что позволяет сплавляться сразу всей группой.

3. Самый романтичный парусный туризм - это не только спорт, но и просто хождение под парусами. Рафт дает возможность как одиночного, так и группового плавания. Кроме парусных яхт также используют байдарки, катамараны, шлюпы.

4. Одним из самых экстремальных видов туризма является дайвинг, или подводное погружение, даже для самого кратковременного погружения под воду необходимо обучение. У этого вида туризма есть огромный плюс, им можно заниматься круглый год. Вместе с тем дайвинг является достаточно дорогим видом спорта, набирающим популярность в России.

5. Каякинг - это плавание на быстроходных вытянутых лодках «Каяк». Это спортивный и активный вид отдыха достаточно разнообразен: 1) прогулки и путешествия по спокойной водной поверхности озера, морских заливов, равнинных рек; 2) каякинг с преодолением препятствий в бурном потоке воды; 3) родео или фристайл на воде, когда выполняются акробатические трюки во время неоднородных потоков воды.

6. Водные лыжи - популярный вид летнего развлечения и спорта, когда катание по поверхности воды происходит на специальных лыжах, держась за фал (трос), закрепленный за катером (моторной лодкой), обеспечивающим тягу водного лыжника. С 2009 г. водным лыжам присвоен статус олимпийского вида спорта [4].

7. Вейкбординг - одна из разновидностей буксировки за катером.

8. Рыбалка является одним из самых древних видов водного спорта. Например, в Бурятии многие базы отдыха и туристические фирмы, расположенные на берегах водоемов, предлагают различные рыболовные туры для фанатов рыбалки. Это могут быть настоящие рыболовные путешествия, от сплавов по диким рекам и ночевок на необитаемых берегах до современных рыболовных отелей с высоким уровнем сервиса.

Таким образом, водный туризм как вид активного отдыха предполагает путешествие, позволяющее отдохнуть, увидеть в пути красивые природные ландшафты, познакомиться с культурой и историей народов, их достопримечательностями, знакомство с участниками группы и людьми, проживающими в населенных пунктах по маршруту путешествия.

Авторами был проведен анализ рынка водного туризма в Республике Бурятия (табл. 1).

Таблица 1

Характеристика водных туров в Республике Бурятия

\begin{tabular}{|c|l|l|}
\hline Район & \multicolumn{1}{|c|}{ Река } & \multicolumn{1}{c|}{ Описание сплава } \\
\hline Тункинский & Утулик & Предназначен для туристов, имеющих опыт спла- \\
& & ва, и для посещения гор (можно груз на конях). \\
& & 50 км трекинга через перевал по тропе Байкала, \\
& & водопады, вершины (Хамар-Дабан). Сплав 50 км \\
& & - короткий без плесов. Несколько сложных и \\
\hline
\end{tabular}


И. И. Старкова, Е. А. Крыласова, Л. Г. Доржиева. Водный туризм как одно из направлений в рекреации

\begin{tabular}{|c|c|c|}
\hline & & $\begin{array}{l}\text { красивых порогов } 5 \text { к. с. - Чижик, Мангутайский, } \\
\text { Б. Мордоворот - обносятся при необходимости } \\
\text { легко. Много хариуса }\end{array}$ \\
\hline Кабанский & Снежная & $\begin{array}{l}\text { Вертолетная или «тракторная» заброска для спла- } \\
\text { ва } 150 \text { км (р. Шибетуй) и } 100 \text { км (р. Байри). } \\
\text { В верховьях реки - хорошая рыбалка на хариуса } \\
\text { и ленка. Довольно полноводная река - много- } \\
\text { численные мощные и слаломные пороги 3-4 к. с. } \\
\text { Наличие порогов } 5 \text { к. с. (Монгулгольский, Серая } \\
\text { Ямка) и } 6 \text { к. с. (Жаба и Снежинка) привлекает и } \\
\text { туристов с опытом }\end{array}$ \\
\hline Тункинский & Хара Мурин & $\begin{array}{l}\text { Вертолетная заброска или пешком. } 150 \text { слалом- } \\
\text { ных порогов от р. Нарин Гол, из них - четыре } 5 \text { к. } \\
\text { с. и десяток } 4 \text { к. с. Хорошая рыбалка на хариуса. } \\
\text { Верхний каньон } 6 \text { к. с. (выше притока Дзымха) } \\
\text { популярен и посещаем каякерами. Водный марш- } \\
\text { рут 4+ к. с. - от слияния с рекой Нарин Гол. Далее } \\
\text { сплав } 30 \text { км с порогами } 4 \text { к. с. и порогом Рубикон } \\
\text { - 5-6 к. с. легко обносится. Долина расширяется } \\
\text { и опять входит в ущелье «Сойбатское» с } 20 \text { поро- } \\
\text { гами 4-5 к. с. }\end{array}$ \\
\hline $\begin{array}{l}\text { У геоморфоло- } \\
\text { гов нет едино- } \\
\text { го мнения к } \\
\text { какой горной } \\
\text { системе отно- } \\
\text { сится данный } \\
\text { район: некото- } \\
\text { рые считают } \\
\text { его частью Ха- } \\
\text { мар-Дабана, } \\
\text { некоторые - } \\
\text { нет. Бесспорно } \\
\text { только то, что к } \\
\text { востоку от } \\
\text { данного райо- } \\
\text { на расположе- } \\
\text { ны горы Ха- } \\
\text { мар-Дабана, а } \\
\text { к западу - } \\
\text { Восточного } \\
\text { Саяна. }\end{array}$ & $\begin{array}{l}\text { Хангарульский } \\
\text { хребет. р. Зун } \\
\text { Морин и его } \\
\text { притоки р. } \\
\text { Хангарул, Хун- } \\
\text { гудей }\end{array}$ & $\begin{array}{l}\text { Регион схож по климату с Хамар-Дабаном, но не- } \\
\text { много суше. Река впадает в р. Иркут. В горах Хан- } \\
\text { гарульского хребта можно совершить трекинг и } \\
\text { конные маршруты по необычным столовым горам } \\
\text { до } 2700 \text { м высотой. Четыре сплавные реки - } \\
\text { М. Ургудей, Б. Ургудей, Зун Мурин и Хангарул. } \\
\text { Тумусун и Маргасан для байдарки. Необычный и } \\
\text { особенный горный район }\end{array}$ \\
\hline Тункинский & Хангарул & $\begin{array}{l}\text { Жемчужина Прибайкалья. Хангарул - красивая, } \\
\text { рыболовная река. Пороги 3-4 к. с. Заброска вер- } \\
\text { толетом или конный тур и заброска от п. Жемчуг. } \\
\text { Сплав и рыбалка }\end{array}$ \\
\hline Тункинский & $\begin{array}{l}\text { Зун-Мурин } \\
\text { (Мурэн) }\end{array}$ & $\begin{array}{l}\text { Крупная по бассейну река. Пользуется популярно- } \\
\text { стью у рыбаков-туристов. Неспешный сплав 3-4 }\end{array}$ \\
\hline
\end{tabular}




\begin{tabular}{|c|c|c|}
\hline & & $\begin{array}{l}\text { к. с. Удивительные места в среднем участке, где } \\
\text { река петляет в ущелье. До пор. Шурик устраивают } \\
\text { туры на водноморных судах. Рыбы на этом участке } \\
\text { нет. Фактически после пор. Шурик идет простой } \\
\text { выкат с реки } 70 \text { км с шиверами } 3 \text { к. с. }\end{array}$ \\
\hline Тункинский & Иркут & $\begin{array}{l}\text { Верхний участок } 50 \text { км (в районе пос. Монды) - } \\
\text { традиционный участок для похода выходного дня. } \\
\text { Мимо этого участка проходит автозаброска на } \\
\text { реки Ока Саянская, Урик и Китой. Вообще Верхний } \\
\text { Иркут продолжается с порогами и дальше до пос. } \\
\text { Шимки. От моста на Нилова Пустынь до Шимок - } \\
25 \text { км с несколькими порогами } 3 \text { к. с. Средний Ир- } \\
\text { кут (Зырказунское ущелье } 80 \text { км) популярен как } \\
\text { тур выходного дня - } 2 \text { к. с. Отличный маршрут с } \\
\text { детьми на } 2 \text { дня как завершающий или начинаю- } \\
\text { щий отдых на Байкале. Достаточно динамично - } \\
\text { аналог Катуни от Чемала только в красивом гор- } \\
\text { ном ущелье }\end{array}$ \\
\hline Тункинский & Китой & $\begin{array}{l}\text { Легендарная река } 5 \text { к. с. Сроки для нормального } \\
\text { сплава } 5 \text { к. с. - август/сентябрь. Рыбалка на тай- } \\
\text { меня и ленка. Первый этап до Верхнего каньона } \\
30 \text { км в окружении горных вершин в виде замков } \\
\text { несложный. Верхний каньон } 2 \text { км - обнос водо- } \\
\text { пада } 100 \text { м. Сплав четырех порогов - Веретено и } \\
\text { Винт } 5 \text { к. с., Нежданный } 4 \text { к. с. и Выходной } 3 \text { к. с. } \\
\text { Далее } 40 \text { км динамичного сплава до Моткиных } \\
\text { Щек - пороги 4+к. с. В каньоне обнос порога и } \\
\text { водопада } 600 \text { м. В каньоне } 40 \text { порогов } 4-5 \text { к. с. }\end{array}$ \\
\hline Тункинский & Шумак & $\begin{array}{l}\text { Особенно интересен в плане организации комби- } \\
\text { нированного пеше-, конно-, водного тура маршру- } \\
\text { та. После недельного маршрута в горах сплав по } \\
\text { реке Шумак (с обносом каньона) и Китой }-4 \text { к. с. } \\
\text { Для спортивных туристов и рыболовов с опытом и } \\
\text { без }\end{array}$ \\
\hline Окинский & Ара Ошей & $\begin{array}{l}\text { Горы в верховьях р. Ара Ошея очень красочны. } \\
\text { Пеший выход в окружающие лабиринты гор. Река } \\
\text { 4+к. с. Есть водопад }\end{array}$ \\
\hline Еравнинский & Билюты & $\begin{array}{l}\text { По сути каякерная речка IV кл. - красивые водо- } \\
\text { пады, каньоны }\end{array}$ \\
\hline Окинский & Онот & $\begin{array}{l}\text { Одна из самых сложных легендарных и красивых } \\
\text { Саянских рек - } 150 \text { км сплав. Более ста препят- } \\
\text { ствий и более } 30 \text { порогов 5-6 к. с. Несколько ка- } \\
\text { ньонов с водопадами }\end{array}$ \\
\hline Закаменский & Темник & $\begin{array}{l}\text { Тракторная заброска с тайменной рыбалкой по } \\
\text { реке } 4 \text { к. с. Разбивка лагеря перед заповедником и } \\
\text { каньоном с порогами. Прохождение каньона с } \\
\text { десятком порогов и порогом Тоннель } 6 \text { к. с. - }\end{array}$ \\
\hline
\end{tabular}


И. И. Старкова, Е. А. Крыласова, Л. Г. Доржиева. Водный туризм как одно из направлений в рекреации

\begin{tabular}{|l|l|l|}
\hline & & $\begin{array}{l}\text { возвращение пешком по тропе 5 км к базовому } \\
\text { лагерю и вертолетная или конная выброска. Ры- } \\
\text { балка на тайменя и ленка. Пороги 4-5 к. с. 150 км } \\
\text { сплава. Впадает в Гусиное озеро в Забайкалье }\end{array}$ \\
\hline Селенгинский & Селенга & $\begin{array}{l}\text { Однодневный сплав на плоту по реке Селенге в } \\
\text { Селенгинском районе - сплав проходит на двух- } \\
\text { этажном моторном плоту площадью } 40 \text { м². В про- } \\
\text { грамме тура посещение исторических и природ- } \\
\text { ных достопримечательностей Селенгинского рай- } \\
\text { она }\end{array}$ \\
\hline Селенгинский & Селенга & $\begin{array}{l}\text { Сплав «Просторы Селенги» на плоту по р. Селен- } \\
\text { ге- 2-дневный сплав проходит на двухэтажном } \\
\text { моторном плоту площадью 40 м². В программу } \\
\text { тура входит посещение исторических и природных } \\
\text { достопримечательностей акватории р. Селенги }\end{array}$ \\
\hline Селенгинский & Озеро Гусиное \\
& $\begin{array}{l}\text { Выходной день на оз. Гусиное - тур выходного } \\
\text { дня на двухэтажном плоту «Дичалый с площадью } \\
\text { 70 м². Отдых включает в себя солнечные ванны, } \\
\text { теплую воду, барбекю, прогулки по озеру, рыбал- } \\
\text { ку, фотосессию, экстремальную «нырялку", } \\
\text { снорклинг }\end{array}$ \\
\hline
\end{tabular}

Республика Бурятия богата реками и водоемами, практически всюду есть возможность сплавляться. Вместе со спортивным также распространен коммерческий рафтинг. Не все сложные и интересные с точки зрения рафтинга маршруты имеют удобные подъезды. Отсутствие инфраструктуры, железных и автомобильных дорог во многих районах республики делает развитие водного туризма в этих местах дорогим и малодоступным удовольствием для туристов. Развитие туризма требует решения многих сопутствующих задач: улучшения качества транспортной системы, предприятий питания, туристического имиджа, информационной инфраструктуры, а также обучения квалифицированных специалистов и повышение качества обслуживания.

\section{Лuтература}

1. Долженко Г. П., Путрик Ю. С. История туризма в Российской империи, Советском Союзе и Российской Федерации. М.; Ростов н/Д., 2010. 211 с.

2. Лакомов Е. А. Повышение конкурентоспособности регионов России на основе развития услуг по событийному туризму: дис. ... канд. экон. наук: 08.00.05. М., 2013. $202 \mathrm{c}$.

3. Маркетинг: учеб. пособие / под ред. И. М. Синяевой. М.: ИНФРА-М, 2011. 384 с.

4. Мерзлова М. П., Качурина М. М. Актуальные аспекты развития инвестиционного климата в сфере туризма // Сервис Plus. 2014. № 2. С. 73. 


\section{WATER TOURISM AS ONE OF THE MODERN TRENDS IN RECREATION}

Irina I. Starkova

Cand. Sci. (Sociol.), A/Prof.,

Dorzhi Banzarov Buryat State University

24a Smolina St., Ulan-Ude 670000, Russia

E-mail: irina-ivanovna.8@mail.ru

Ekaterina A. Krylasova

Senior Lecturer,

Dorzhi Banzarov Buryat State University

24a Smolina St., Ulan-Ude 670000, Russia

E-mail: krylasova@yandex.ru

Larisa G. Dorzhieva

Cand. Sci. (Education), Senior Lecturer,

Dorzhi Banzarov Buryat State University

24a Smolina St., Ulan-Ude 670000, Russia

E-mail: lara.dorzhieva@yandex.ru

The Republic of Buryatia is a very attractive region in terms of the development of water tourism. Water tourism in Buryatia has a great potential for the favorable development of domestic tourism and the reception of Russian and foreign tourists. Water tourism is one of the types of sports tourism, which is characterized by clearing obstacles on the water surface. It provides an opportunity for both active and passive relaxation. The article presents the classification of water tourism as a separate trend in modern recreation. We have concluded that water tourism combines the elements of cognition, outdoor activities, recreation and sports and is accessible to all healthy people.

Keywords: recreation; water tourism; tourism; leisure time; organization of leisure time. 